\title{
MICROBIOLOGICAL LEACHING; AN ENVIRONMENTALLY FRIENDLY AND COST EFFECTIVE METHOD FOR EXTRACTION OF METALS
}

Mehdi GHOBEITI-HASAB * and Zahra KHOSHNOOD **

* Department of Metallurgy and Materials, Faculty of Engineering, Dezful Branch, Islamic Azad University, Dezful, Iran, ghobeiti@iaud.ac.ir

** Faculty of Science, Dezful Branch, Islamic Azad University, Dezful, Iran, zkhoshnood@gmail.com

KEYWORDS: Bio-leaching, bio-oxidation, bacteria.

DOI: 10.2478/trser-2018-0010

\section{ABSTRACT}

Finding a cleaner, environmentally friendly and cost-effective way of metal and mineral extraction has a great importance in today's world. Using microorganisms in bioleaching and bio-oxidation process is of great value. From Archaea to bacteria and fungi, microorganisms can play an important role in extraction of metals from mine drainage and unaccessible sources, both in aquatic and terrestrial environments. Optimization of environmental factors such as the temperature, $\mathrm{pH}$ and substrate concentration is crucially important to access the optimum extraction of selected metals from an ore or mine drainage. The present paper will review the bio-leaching and bio-oxidation process of minerals with emphasis on the most wellknown species of bacterial communities of such ability, through the literature.

RESUMEN: La lixiviation microbiologique; une méthode écologique et rentable pour l'extraction des métaux.

Trouver une façon plus propre, respectueuse de l'environnement et économique de l'extraction des métaux et des minéraux est d'une grande importance dans le monde d'aujourd'hui. L'utilisation de microorganismes dans le processus de bio-lixiviation et de biooxydation est d'une grande valeur. De l'Archaea aux bactéries et aux champignons, les microorganismes peuvent jouer un rôle important dans l'extraction des métaux du drainage des mines et des sources non accessibles, tant dans les milieux aquatiques que terrestres. L'optimisation des facteurs environnementaux tels que la température, le $\mathrm{pH}$ et la concentration du substrat est cruciale pour accéder à l'extraction optimale des métaux sélectionnés à partir d'un minerai ou d'un drainage minier. Le présent document examinera le processus de bio-lixiviation et de bio-oxydation des minéraux, en mettant l'accent sur les espèces les plus connues de communautés bactériennes de cette capacité, à travers la littérature.

REZUMAT: Lixivierea microbiologică; o metodă ieftină și ecologică de extragere a metalelor.

În contextul internațional actual, găsirea unei metode mai ecologice, mai puțin poluante și ieftine de extragere a metalelor și minereurilor este de mare importanță. O deosebită valoare este reprezentată de utilizarea microorganismelor în procese bio-oxidative și de bio-lixiviere. De la Archaea la bacterii și fungi, microorganismele pot juca un rol important în extragerea metalelor din apele de mină și din surse inaccesibile atât în mediu terestru cât și acvatic. Optimizarea factorilor ambientali precum temperatura, $\mathrm{pH}-\mathrm{ul}$ și concentrația substratului sunt cruciale pentru o extragere optimă a metalelor selecționate din zăcământ sau din apele de mină. Articolul de față trece în revistă procesele de extragere a mineralelor prin bio-oxidare şi bio-lixiviere, evidențiind cele mai bine cunoscute specii din comunitățile bacteriene cu astfel de abilități, așa cum sunt ele prezentate în literatura de specialitate. 


\section{INTRODUCTION}

Excavation of mines for different minerals extraction is one of the most destructive anthropogenic activities for terrestrial and aquatic ecosystems. Such activities affect the topography, turbidity, concentration of dissolved particles and minerals, $\mathrm{pH}$, etc. and could affect the life of inhabited organisms directly or indirectly (Ashton et al., 2001).

Microorganisms are one of the most abundant living organisms of all ecosystems from terrestrial to aquatic habitats. Different classes of such organisms have biological, chemical, and physical effects on their surrounding environments. Using microorganisms for extraction of wide range of minerals and biological products is an effective and environmentally friendly way to use the new sources of minerals and metals which cannot be extracted using common and ordinary methods (Edwards et al., 2013).

Using the microorganisms, especially the bacteria and fungi, is a clean way of extracting minerals and metals from the wastewater of industries as well. Thereby the process called bio-leaching, which means the dissolution of metals from their mineral source using microorganisms, or using microorganisms to transform elements of certain ore to a kind of soluble form which could easily accessible by washing the ore by aqueous solutions. These processes also could be named as bio-oxidation (Rajkumar et al., 2010).

Many sulphide ores known as refractory ores e.g. pyrite $\left(\mathrm{FeS}_{2}\right)$, arsenopyrite (FeAsS) and pyrrhotite (FeS) include gold as fine dispersed particles and encapsulated in the sulphide matrix (Fig. 1), so that the gold cannot be recovered by conventional leaching. Roasting as a traditional method for oxidizing sulphides is not acceptable due to economic (high consumption of heat energy and need expensive equipment) and environmental (release of $\mathrm{SO}_{2}$ gas) considerations. In recent years, the development of microbiological leaching has been led to the effective recovery of precious metals from sulphide ores. Using iron and ulphursulphur oxidizing bacteria can accelerate the oxidation of sulphides and the liberation of gold. The bacteria gain energy by oxidizing $\mathrm{Fe}^{2+}$ and $\mathrm{S}^{0}$ that produce $\mathrm{Fe}^{+3}$ and $\mathrm{H}_{2} \mathrm{SO}_{4}$. However, this process needs a long time (often one week) and precise control to provide the bacterial survival (Bierlein and Wilde, 2010; Liu et al., 2015; Zhang et al., 2016).

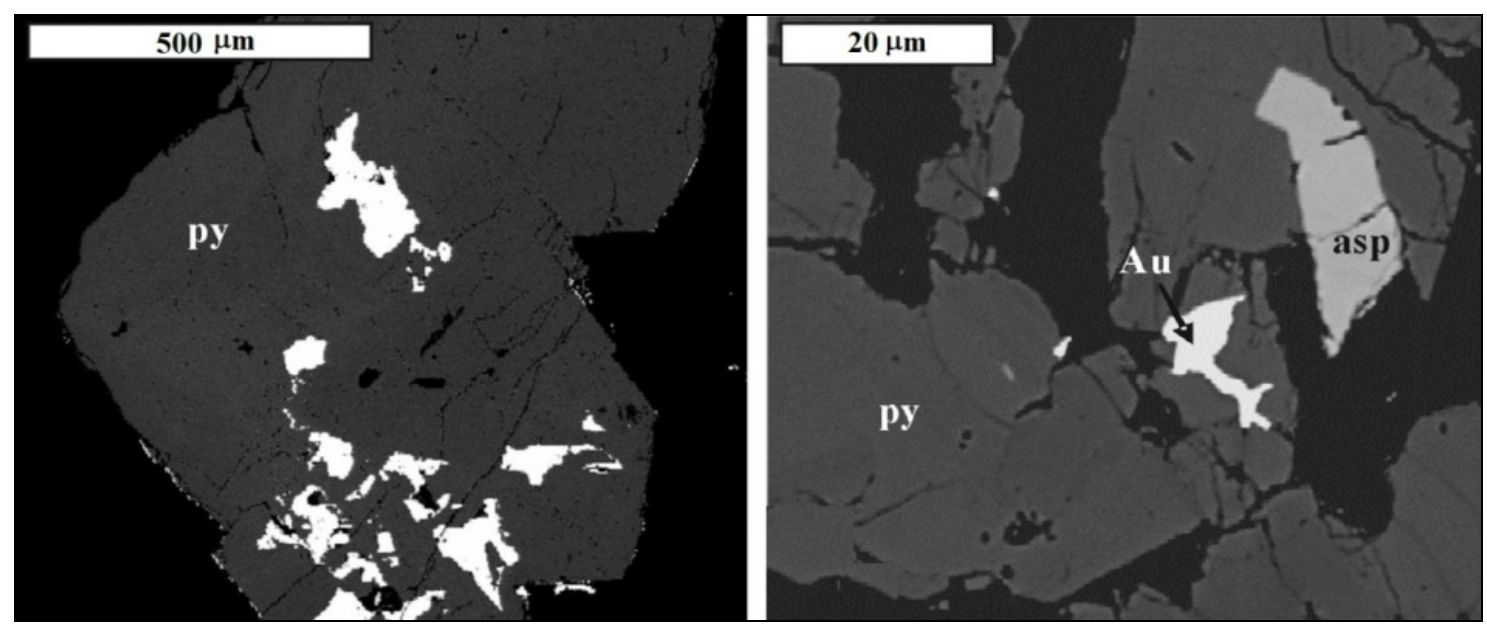

Figure 1: Gold particles encapsulated in the sulphide minerals

(Bierleine and Wilde, 2010). 


\section{Bio-oxidation reactions of ulphursulphur ores}

In bio-oxidation of pyrrhotite ore, the process begins by a chemical step:

$$
\mathrm{FeS}+2 \mathrm{H}^{+} \rightarrow \mathrm{Fe}^{2+}+\mathrm{H}_{2} \mathrm{~S}
$$

Then, bacteria oxidise pyrrhotite according to the following reactions:

$$
\begin{gathered}
2 \mathrm{FeS}+4.5 \mathrm{O}_{2}+3 \mathrm{H}^{+} \rightarrow 2 \mathrm{Fe}^{3+}+\mathrm{SO}_{4}{ }^{2-}+\mathrm{HSO}_{4}^{-}+\mathrm{H}_{2} \mathrm{O} \\
2 \mathrm{FeS}+1.5 \mathrm{O}_{2}+6 \mathrm{H}^{+} \rightarrow 2 \mathrm{Fe}^{3+}+2 \mathrm{~S}^{0}+3 \mathrm{H}_{2} \mathrm{O}
\end{gathered}
$$

Sulphur is also produced by $\mathrm{H}_{2} \mathrm{~S}$ decomposition:

$$
\mathrm{H}_{2} \mathrm{~S}+2 \mathrm{Fe}^{3+} \rightarrow 2 \mathrm{Fe}^{2+}+2 \mathrm{H}^{+}+\mathrm{S}^{0}
$$

Then a chemical reaction between $\mathrm{FeS}$ and $\mathrm{Fe}^{3+}$ takes place:

$$
\mathrm{FeS}+2 \mathrm{~F}^{3+} \rightarrow 3 \mathrm{Fe}^{2+}+\mathrm{S}^{0}
$$

Finally, bacteria oxidise ulphursulphur:

$$
2 \mathrm{~S}^{0}+3 \mathrm{O}_{2}+2 \mathrm{H}_{2} \mathrm{O} \rightarrow 2 \mathrm{SO}_{4}^{-}+4 \mathrm{H}^{+}
$$

Therefore, overall bio-oxidation reaction of pyyrotite is:

$\mathrm{FeS}+1.5 \mathrm{O}_{2}+\mathrm{H}_{2} \mathrm{O} \rightarrow \mathrm{SO}_{4}{ }^{2-}+\mathrm{Fe}^{2+}+2 \mathrm{H}^{+}$(Ubaldini et al., 2000)

Overall bio-oxidation reaction of pyrite is similar to above reaction:

$\mathrm{FeS}_{2}+3.5 \mathrm{O}_{2}+\mathrm{H}_{2} \mathrm{O} \rightarrow 2 \mathrm{SO}_{4}{ }^{2-}+\mathrm{Fe}^{2+}+2 \mathrm{H}^{+}$(Ciftci and Akcil, 2010)

In bio-oxidation of arsenopyrite, following reactions take place:

$$
\begin{aligned}
& 4 \mathrm{FeAsS}+11 \mathrm{O}_{2}+2 \mathrm{H}_{2} \mathrm{O} \rightarrow 4 \mathrm{HAsO}_{2}+4 \mathrm{FeSO}_{4} \\
& 4 \mathrm{FeAsS}+13 \mathrm{O}_{2}+6 \mathrm{H}_{2} \mathrm{O} \rightarrow 4 \mathrm{H}_{3} \mathrm{AsO}_{4}+4 \mathrm{FeSO}_{4}
\end{aligned}
$$

Then $\mathrm{Fe}^{2+}$ is oxidized to $\mathrm{F}^{3+}$ :

$$
4 \mathrm{FeSO}_{4}+\mathrm{O}_{2}+2 \mathrm{H}_{2} \mathrm{SO}_{4} \rightarrow 2 \mathrm{Fe}_{2}\left(\mathrm{SO}_{4}\right)_{3}+2 \mathrm{H}_{2} \mathrm{O}
$$

Chemical oxidation of arsenopyrite by ferric sulphate is another reaction along with bio-oxidation process:

$$
\begin{aligned}
& 4 \mathrm{FeAsS}+\mathrm{Fe}_{2}\left(\mathrm{SO}_{4}\right)_{3}+10.5 \mathrm{O}_{2}+3 \mathrm{H}_{2} \mathrm{O} \rightarrow 6 \mathrm{FeSO}_{4}+4 \mathrm{HAsO}_{2}+\mathrm{H}_{2} \mathrm{SO}_{4} \\
& 2 \mathrm{FeAsS}+\mathrm{Fe}_{2}\left(\mathrm{SO}_{4}\right)_{3}+6 \mathrm{O}_{2}+4 \mathrm{H}_{2} \mathrm{O} \rightarrow 4 \mathrm{FeSO}_{4}+2 \mathrm{H}_{3} \mathrm{AsO}_{4}+\mathrm{H}_{2} \mathrm{SO}_{4}
\end{aligned}
$$

$\mathrm{As}^{3+}$ is also oxidized to $\mathrm{As}^{5+}$ as follows:

$$
2 \mathrm{HAsO}_{2}+\mathrm{O}_{2}+2 \mathrm{H}_{2} \mathrm{O} \rightarrow 2 \mathrm{H}_{3} \mathrm{AsO}_{4}
$$

$$
\mathrm{HAsO}_{2}+\mathrm{Fe}_{2}\left(\mathrm{SO}_{4}\right)_{3}+2 \mathrm{H}_{2} \mathrm{O} \rightarrow \mathrm{H}_{3} \mathrm{AsO}_{4}+2 \mathrm{FeSO}_{4}+\mathrm{H}_{2} \mathrm{SO}_{4}
$$

Changing $\mathrm{As}^{3+}$ to $\mathrm{As}^{5+}$ is necessary for decreasing the toxicity of media, improving bacterial activity and thus increasing leaching efficiency (Langhans et al., 1995; Cheng et al., 2010).

\section{Bio-oxidation reaction parameters}

The effective parameters of a bioleaching (or bio-oxidation) process have been described as follows: temperature, $\mathrm{pH}$, culture media, bacterial species and concentration of the ore pulp (Elrich and Brierly, 1990; Elrich, 2001). The main pollutant product of chemical leaching is $\mathrm{SO}_{2}$ gas which is consumed by bacteria in bioleaching process and this latter processes is one of the environmental friendly characteristics of bioleaching (Elrich, 2001).

On the other hand, in chemical leaching, using high concentrations of strong acids such as Nitric Acid, Hypochlorus Acid and Sulphuric Acid and also providing a tank made up of stainless steel and in some cases using a high temperature autoclave for running the chemical reaction were the expensive and complicated parameters of such leaching process. Compared to that, without any needs to chemical hazards or special tank or extreme temperatures, bioleaching could only be conducted by optimizing the culture media for selected organisms, which makes it the most cost-effective and environmentally friendly way for extraction of metals from sulphide ores (Elrich, 2001). 
Also, bio-extraction of metals from waste water of industries, using mesofilic and thermofilic ulphursulphur bacteria for extraction of ulphursulphur from waste water has been previously studied (Elrich and Brierly, 1990). In such experiments, ulphursulphur bacteria such as Acidiothiobacillus ferroxidans and Acidiothiobacillus thiooxidans were used for bioextraction of sulphide from a waste water to clean up the sewage (Fuseler et al., 1996).

\section{Microbial diversity for bioleaching habitats}

A large variety of microorganisms has been segregated from the mining and environmental bio-leaching situations, from bacteria, to fungi and algae. Diverse species have been segregated from a copper mine from different classes of microorganisms such as bacteria (Acidiothiobacillus sp.), yeasts (Rhodotorula sp., Trichosporon sp.), flagellates (Eutrepia sp.), amoebas and protozoa. One of the most important species in bioleaching habitats is Acidiothiobacillus ferrooxidans which is occasionally exchange with Leptospirillum sp. based on environmental elements (Acosta et al., 2014).

Also, a variety of thermophilic microorganisms (especially Sulfolobus sp.) have been enriched and isolated from bio-leaching environments. Table 1 shows a selection of abundant microorganisms of bio-leaching habitats.

Table 1: Some microorganisms of bio-leaching habitats.

\begin{tabular}{|l|l|l|}
\hline Domain & Organism & Main leaching agent \\
\hline Archea & Acidianus ssp. & ulphursulphuric acid \\
\hline & Ferroplasma acidiphilum & ferric iron \\
\hline & Metallosphaera ssp. & ferric iron, ulphursulphuric acid \\
\hline & Sulfolobus ssp. & ferric iron, sulphuric acid \\
\hline & Sulfurococcus ssp. & ferric iron, sulphuric acid \\
\hline & Acetobacter methanolicus & gluconate \\
\hline & Acidiphilium ssp. & organic acids \\
\hline & Bacillus megaterium & citrate \\
\hline & Chromobacterium violaceum & cyanide \\
\hline & Crenothrix ssp. & ferric iron \\
\hline & Gallionella ssp. & ferric iron \\
\hline & Leptospirillum ferrooxidans & ferric iron \\
\hline & Leptothrix discophora & ferric iron, sulphuric acid \\
\hline & &
\end{tabular}


Table 1 (continued): Some microorganisms of bio-leaching habitats.

\begin{tabular}{|l|l|l|}
\hline Domain & Organism & Main leaching agent \\
\hline & Pseudomonas putida & Citrate, gluconate \\
\hline & Siderocapsa ssp. & ferric iron \\
\hline & $\begin{array}{l}\text { Sulfobacillus } \\
\text { thermosulfidooxidans }\end{array}$ & ferric iron, sulphuric acid \\
\hline & Thermothrix thiopara & sulphuric acid \\
\hline & Thiobacillus ssp. & sulphuric acid \\
\hline Eukarya & Thiomonas cuprinus & sulphuric acid \\
\hline Fungi & Altinomucor sp. & succinate \\
\hline & Aspergillus ssp. & citrate, oxalate \\
\hline & Fusarium sp. & $\begin{array}{l}\text { oxalate, citrate, gluconate, malate, tartrate, } \\
\text { succinate }\end{array}$ \\
\hline
\end{tabular}

\section{Bacteria}

Among the all classes of microorganisms, bacteria are the most observed group of bioleaching communities. The most well-known and first identified bio-leaching bacteria are Acidithiobacillus ferrooxidans, Leptospirillum ferrooxidans, Acidithiobacillus thiooxidans and Thiobacillus thiooxidans (Harneit et al., 2006; Lei et al., 2007).

\section{- Acidithiobacillus ferrooxidans}

Acidithiobacillus ferrooxidans belongs to the group of chemolithotrophic organisms. The organism is rod-shaped (usually single or in pairs), non-spore forming, gram-negative, motile, and single-pole flagellated (Jerez, 2009).

Acidithiobacillus ferrooxidans is an acidophilic bacterium. It has obligate autotrophic way of gaining energy, using elementary sulphur, ferrous iron and tetrathionate as electron donors during ATP production. Acidithiobacillus ferrooxidans also is a rod-shaped motile bacterium living in acidic or neutral environments (Fig. 2). Due to its unique characteristics, it is well-known as an economically significant species for bio-leaching process of low- grade sulphide ores. The species is naturally inhabitant of mine drainage and tailings. Also due to high ability of this species in bio-oxidation process, it has been described as a significant species for bioremediation process in contaminated aquatic and terrestrial environments (Sun et al., 2012; Fomchenko et al., 2016). 


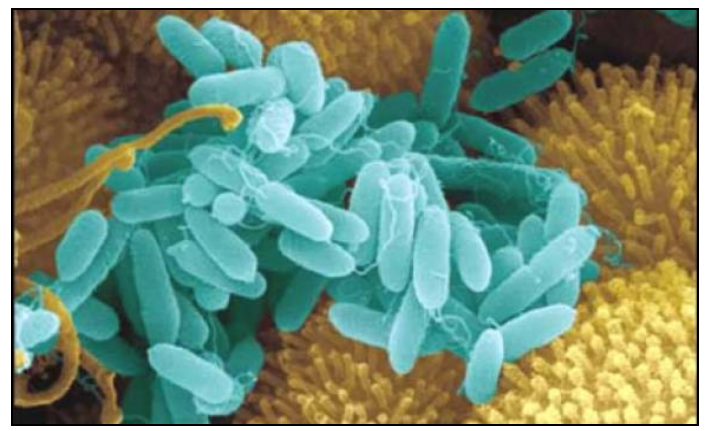

Figure 2: SEM image of Acidithiobacillus ferrooxidans bacteria (Ribeiro et al., 2011).

\section{- Leptospirillum ferrooxidans}

Leptospirillum ferrooxidans is an obligate aerobic bacterium with high ability of ironoxidization and has an important role in bio-leaching and bio-oxidation of industrial activities (Fig. 3). The species is acidophilic and has been known as main component of mine drainage (Corkhill et al., 2008; Liu et al., 2017).
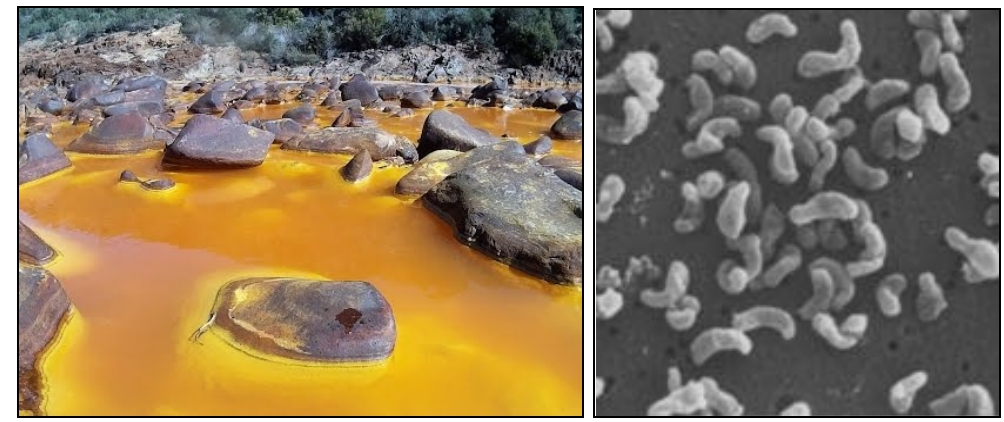

Figure 3: SEM image of Leptospirillum ferrooxidans (right) and drainage containing L. ferrooxidans (left) (Chapana and Tributsch, 2004).

\section{- Acidithiobacillus thiooxidans}

Acidithiobacillus thiooxidans is a sulphur bacteria belongs to gram negative group and has rod-shaped cells which uses sulphur compounds as energy source (Fig. 5). Due to mesophilic properties of this spices and being a natural inhabitant of diverse ecosystems, $A$. thiooxidans has important activities (A. thiooxidans (mesophilic) and A. caldus (thermophilic) oxidize elemental sulphur and sulphur reduced compounds) in bio-oxidation and bio-leaching process (Liu et al., 2003; Harneit et al., 2006; Leng et al., 2009; Khan et al., 2012).

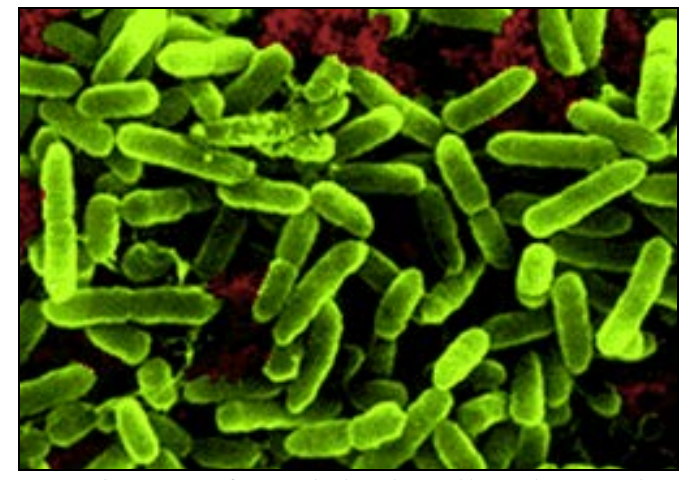

Figure 5: SEM image of Acidithiobacillus thiooxidans bacteria. 


\section{CONCLUSIONS}

Due to increasing risk of anthropogenic activities on biological characteristics of aquatic and terrestrial ecosystems, finding novel methods that are cost-effective and environmentally friendly ways of metal extraction has a great importance in today's world.

Natural microorganism communities of mines and drainage systems are the first object of application as a new method of metal extraction through bio-leaching and bio-oxidation pathways.

Diverse variety of such microorganism from Archaea to bacteria and fungi are among the observed species. The most important factors of application of the microorganism in bioleaching process are the $\mathrm{pH}$, temperature and the concentration of metals and leaching agents in the ecosystem.

Setting up the optimum environmental factors for selected species could lead to a successful extraction of valuable amounts of metals and minerals from mine drainage or inaccessible sources. 


\section{ACKNOWLEDGEMENTS}

We express our special thanks to Reza Khoshnood R. who kindly assisted us in writing of this paper. We are also grateful to Etemadi H. and Amini M. for their valuable helps which led to this manuscript. 


\section{REFERENCES}

1. Acosta M., Galleguillos P., Ghorbani Y., Tapia P., Contador Y., Velásquez A., Espoz C., Pinilla C. and Demergasso C., 2014 - Variation in microbial community from predominantly mesophilic to thermotolerant and moderately thermophilic species in an industrial copper heap bio-leaching operation, Hydrometallurgy, 150, 281-289.

2. Ashton P. J., Love D., Mahachi H., Dirks P. H. G. M., 2001 - An overview of the impact of mining and mineral processing operations on water resources and water quality in the Zambezi, Limpopo and Olifants catchments in Southern Africa, Contract report to the mining, minerals and sustainable development (Southern Africa) Project, by CSIR-Environmentek, Pretoria, South Africa and Geology Department, University of Zimbabwe, Harare, Zimbabwe. Report No. ENV-P-C 2001-042.

3. Bierlein F. P. and Wilde A. R., 2010 - New constraints on the polychronous nature of the giant Muruntau gold deposit from wall-rock alteration and ore paragenetic studies, Australian Journal of Earth Sciences, 57, 839-854.

4. Chapana J. A. R. and Tributsch H., 2004 - Interfacial activity and leaching patterns of Leptospirillum ferrooxidans on pyrite, Journal of Microbiology and Ecology, 47, 19-29.

5. $\quad$ Cheng C. R., Ying Y. H., Sen C., Shuo Z. and Feng L. K., 2010 - Valence variation of arsenic in bioleaching process of arsenic-bearing gold ore, Transactions of Nonferrous Metals Society of China, 20, 1171-1176.

6. Ciftci H. and Akcil A., 2010 - Effect of biooxidation conditions on cyanide consumption and gold recovery from a refractory gold concentrate, Hydrometallurgy, 104, 142-149.

7. $\quad$ Corkhill C. L., Wincott P. L., Lloyd J. R. and Vaughan D. J., 2008 - The oxidative dissolution of arsenopyrite (FeAsS) and enargite (Cu3AsS4) by Leptospirillum ferrooxidans, Geochimica et Cosmochimica Acta, 72, 5616-5633.

8. $\quad$ Edwards C. D., Beatty J. C., Loiselle J. B., Vlassov K. A. and Lefebvre D. D., 2013 - Aerobic transformation of cadmium through metal sulfide biosynthesis in photosynthetic microorganisms, Biomedical central Microbiology, 13, 1, 161-172.

9. Elrich H. L., 2001 - Past, present and future of biohydrometallurgy, Hydrometallurgy, 59, 127-134.

10. Elrich H. L. and Brierley C. L., 1990 - Microbial Recovery 1st edition, Mc Graw-Hill publishing company, 3-27.

11. Fomchenko N. V., Kondrateva T. F. and Muravyov M. I., 2016 - A new concept of the biohydrometallurgical technology for gold recovery from refractory sulfide concentrates, Hydrometallurgy, 164, 78-82.

12. Fuseler K. Krekeler D. Sydow U. and Cypionka H., 1996 - A common pathway of sulfide oxidation by sulfat- reducing bacteria, Federation of European Microbiological Societies Microbiology Letters, 144, 129-134.

13. Harneit K., Goksel A., Kock D., Klock J. H., Gehrke T. and Sand W., 2006 - Adhesion to metal sulfide surfaces by cells of Acidithiobacillus ferrooxidans, Acidithiobacillus thiooxidans and Leptospirillum ferrooxidans, Hydrometallurgy, 83, 245-254.

14. Jerez C. A. 2009 - Metal extraction and biomining, in The desk encyclopedia of microbiology; Schaechter M. (ed.), Elsevier, Oxford, UK, 762-775.

15. Khan S., Haq F., Hasan F., Saeed K. and Ullah R., 2012 - Growth and biochemical activities of Acidithiobacillus thiooxidans collected from black shale, Journal of Microbiology Research, 2, 78-83.

16. Langhans D., Lord A., Lampshire D., Burbank A. and Baglin E., 1995 - Bio-oxidation of an arsenic-bearing refractory gold ore, Minerals Engineering, 8, 147-158.

17. Lei J., Yang Z. H. and Tong P. X., 2007 - Bio-oxidation of pyrite, chalcopyrite and pyrrhotite by Acidithiobacillus ferrooxidans, Chinese Science Bulletin, 52, 2702-2714. 
18. Leng F., Li K., Zhang X., Li Y., Zhu Y., Lu J. and Li H., 2009 - Comparative study of inorganic arsenic resistance of several strains of Acidithiobacillus thiooxidans and Acidithiobacillus ferrooxidans, Hydrometallurgy, 98, 235-240.

19. Liu H. L., Chen B. Y., Lan Y. W. and Cheng Y. C. 2003 - SEM and AFM images of pyrite surfaces after bioleaching by the indigenous Thiobacillus thiooxidans, Applied Microbiology and Biotechnology, 62, 414-420.

20. Liu X. X., Wang G. H., Huo Q., Xie J. P., Li S. P., Wu H. Y. and Guo Y. J., 2015 - Novel two-step process to improve efficiency of bio-oxidation of Axi high-sulphur refractory gold concentrates, Transactions of Nonferrous Metals Society of China, 25, 4119-4125.

22. Liu J., Wu W., Zhang X., Zhu M. and Tan W., 2017 - Adhesion properties of factors influencing Leptospirillum ferriphilum in the biooxidation of refractory gold-bearing pyrite, International Journal of Mineral Processing, 160, 39-46.

23. Ribeiro D. A., Maretto D. A., Nogueira F. C. S., Silva M. J., Campos F. A. P., Domont G. B., Poppi R. J. and Ottoboni L. M. M., 2011 - Heat and phosphate starvation effects on the proteome, morphology and chemical composition of the biomining bacteria Acidithiobacillus ferrooxidans, World Journal of Microbiology and Biotechnology, 27, 1469-1479.

24. Sun L. X., Zhang X., Tan W. S. and Zhu M. L., 2012 - Effect of agitation intensity on the biooxidation process of refractory gold ores by Acidithiobacillus ferrooxidans, Hydrometallurgy, 127-128, 99-103.

25. Ubaldini S., Veglio F., Beolchini F., Toro L. and Abbruzzese C., 2000 - Gold recovery from a refractory pyrrhotite ore by biooxidation, International Journal of Mineral Processing, 60, 247-262.

26. Zhang X., Feng Y. L. and Li H. R., 2016 - Enhancement of bio-oxidation of refractory arsenopyritic gold ore by adding pyrolusite in bioleaching system, Transactions of Nonferrous Metals Society of China, 26, 2479-2484. 